\title{
LUGARES/OLHARES DES-LOCADOS E A CONFIGURAÇÃO DO ESPAÇO DO OUTRO EM ATONEMENT, DE IAN MCEWAN, E NA ADAPTAÇÃO FÍLMICA, DE JOE WRIGHT
}

\section{DIS-PLACED SITES/SIGHTS AND THE CONFIGURATION OF OTHERNESS' SPACE IN IAN MCEWAN'S ATONEMENT AND IN JOE WRIGHT'S FILM ADAPTATION ${ }^{1}$}

Lucia Fatima Fernandes Nobre Universidade Federal da Paraíba

\section{Resumo}

A problematização de categorias dicotômicas num mundo plural, heterogêneo e contraditório, cujas fronteiras sócio-artística-culturais são questionadas e confrontadas, impulsiona o artista a olhar para regimes estéticos que apropriadamente busquem o enfrentamento destas questões. A metaficção, como um fenômeno estético, intencionalmente autorreferencial e autorreflexivo, se adéqua às exigências da arte contemporânea. Associada à paródia, a metaficção produz uma forma artística de leitura sofisticada e também impõe um novo olhar crítico-teórico para alcançar esta complexidade. Neste trabalho, elegemos como recorte de análise a cena da fonte no romance Atonement, de Ian McEwan e na sua adaptação fílmica homônima, do diretor Joe

\begin{tabular}{|l|l|l|l|l|}
\hline Ilha do Desterro & Florianópolis & n 65 & p. 147- 184 & jul/dez 2013 \\
\hline
\end{tabular}


Wright. Com o objetivo de refletir sobre o lugar e o olhar des-locados da personagem-escritora Briony Tallis e sua consequente jornada em busca de uma auto-justificação, investigamos a elaboração das narrativas metaficcionais nos recortes literário e fílmico e observamos que o conflito entre ética e estética resulta na configuração do espaço do outro.

Palavras-chave: Metaficção; Paródia; Atonement; Filme; Alteridade; Espaço

\section{Abstract}

The problematization of dichotomies in a plural, heterogeneous, and contradictory world, whose socio-artistic-cultural borders are questioned and confronted, motivates the artist to look for aesthetical regimes that may appropriately face these questions. Metafiction, as an intentionally auto-referential and auto-reflexive aesthetical phenomenon, is adequate to cope with the requirements of contemporary art. Associated with parody, metafiction produces an artistic form that asks for a sophisticated reading and also demands new critical and theoretical approaches that could deal with such complexity. For the present analyses, we select the scene of the fountain in Ian McEwan's novel Atonement and its correspondent in the film adaptation, by the director Joe Wright. With the objective of reflecting about the dis-placed site and sight of the character-writer Briony Tallis and her consequent effort to perform her auto-justification, we investigate the elaboration of metafictional narratives in the selected material and we notice that the conflict between ethics and aesthetics results in the configuration of the other's space.

Keywords: Metafiction; Parody; Atonement; Film; Alterity; Space. 


\section{Introdução}

Num mundo caracteristicamente plural, heterogêneo e contraditório, onde fronteiras sócio-artística-culturais mostram-se cada vez mais fluidas e categorias binárias são questionadas e confrontadas, o artista volta seu olhar para regimes estéticos que apropriadamente busquem o enfrentamento destas questões. A metaficção, como um fenômeno estético, intencionalmente autorreferencial e autorreflexivo, que orienta o modo de representatividade na arte, satisfaz esta demanda da arte contemporânea. Patricia Waugh ressalta o aspecto perquiridor da metaficção ao defini-la como a "escrita ficcional que auto-consciente e sistematicamente dirige a atenção para seu status como um artefato com a finalidade de questionar a relação entre a ficção e a realidade" $(1984 \text {, p. 2) })^{2}$. Por sua vez, Linda Hutcheon afirma que a paródia é uma forma perfeita, "pois paradoxalmente incorpora e desafia aquilo que parodia” (2000, p. 11). Aliada à paródia, a metaficção é sobremaneira adensada, resultando numa forma artística de leitura sofisticada, que requer um inovador olhar crítico-teórico para fazer jus à sua complexidade. Neste sentido, buscando na própria obra respaldo para sua base analítica-metodológica, elegemos como recorte de análise a cena da fonte no romance Atonement, de Ian McEwan e na sua adaptação fílmica homônima, do diretor Joe Wright. Ao investigar a elaboração das narrativas metaficcionais nos recortes literário e fílmico, intentamos refletir sobre o lugar e o olhar des-locados da personagem-escritora Briony Tallis e sua consequente jornada em busca de uma auto-justificação que possa expurgá-la da culpa pelas mortes precoces de Cecilia (sua irmã) e de Robbie Turner. Tal jornada, no entanto, se traduz num conflito entre ética e estética, que resulta na configuração do espaço do outro.

Em termos estruturais, a passagem em análise consiste num des- 
dobramento narrativo, problematizado pelas diferentes focalizações. Este tipo de desdobramento gera micronarrativas que se contrapõem em perspectiva, mas, de modo paradoxal, se complementam em termos diegéticos, contribuindo para a construção da metaficcionalidade do texto. Portanto, a focalização e a instância narrativa são as principais categorias a serem analisadas nesta passagem literária, o que, obviamente, demanda a busca de suportes teóricos que satisfaçam as exigências do texto. De fato, a mesma história desdobra-se em duas versões, com focalização em Cecilia na primeira versão e focalização em Briony na segunda versão. A primeira versão, que corresponde a todo a capítulo dois da primeira parte do romance, culmina com o despertar do desejo de Robbie por Cecilia; e a segunda versão, que corresponde à segunda metade do capítulo três, traz a interpretação de Briony sobre a cena da fonte, cujos desdobramentos resultam no 'crime' de Briony e na prisão de Robbie. Entretanto, elementos metaficcionais desestabilizadores, como a carta do editor e a questão da 'autoria' de Briony, problematizam a focalização, exigindo novas leituras do texto. Nas versões da cena da fonte, destacamos a dramatização do ato de leitura, agenciado pela metaficção, exigindo do leitor o engajamento na construção do sentido do texto e, paradoxalmente, provocando o estranhamento pela visibilidade do fazer ficcional.

\section{A primeira versão da cena da fonte no romance}

Devido à focalização em Cecilia, destacamos nesta passagem da fonte a tensão emocional existente entre ela e Robbie. Ressaltamos que a focalização em Cecilia possibilita a introdução da história de amor e dos temas do desejo e da paixão no romance. O desconforto que um sente na presença do outro provoca em Cecilia inquietação 
e irritação, enquanto que em Robbie, este estado de espírito reflete-se num certo comportamento cerimonioso que o distancia mais do que o aproxima de Cecilia. A tensão acumulada nos anos de silêncio entre Celicia e Robbie, passados na universidade, explode na disputa por um vaso de porcelana. E da irritação de Cecilia nasce o impulso para mergulhar na fonte, como uma forma de contrariar Robbie. Porém, a visão de Cecilia, como uma ninfa, emergindo da água da fonte, desperta o desejo de Robbie por ela, ou melhor, traz à tona o fogo da paixão, já latente no seu íntimo.

É esta visão que irá inspirar Robbie a escrever a versão erótica do bilhete enviado a Cecilia. De modo interessante, a história de amor de Robbie e Cecilia surge 'tempestuosamente' debaixo dos olhos de Tritão ${ }^{3}$. Conforme Commelin (s.d, p. 115), "[o]s poetas atribuem a Tritão um outro ofício além de arauto de Netuno: o de acalmar as ondas e fazer cessar as tempestades". Ironicamente, é Robbie quem encosta a palma da mão sobre a água da fonte "como que para acalmá-la" (Atonement ${ }^{4}$, p. 39), desconstruindo a função poética atribuída a Tritão. Aliás, o Tritão da fonte dos Tallis dá já sinais claros de decadência, observados na seguinte descrição:

Dos quatro golfinhos cujas caudas sustentavam a concha sobre a qual o Tritão se equilibrava, o mais próximo a Cecilia tinha a boca escancarada entupida com musgos e algas. Seus olhos de pedra esféricos, grandes como maçãs, eram de um verde iridescente. Toda a estátua havia adquirido, no lado voltado para o norte, uma pátina de um azul esverdeado, de modo que, visto de certos ângulos e na penumbra, o musculoso Tritão realmente parecia estar cem léguas abaixo da superfície do mar. A intenção de Bernini deve ter sido de que a água escorresse sonoramente da concha larga, com bordas irregulares, sobre a bacia, que ficava abaixo. Mas a pressão era tão fraca, que a água escorria silen- 
ciosamente pela face inferior da concha, onde um limo oportunista pendia dos pontos de água que gotejava, como estalactites numa caverna de calcário (p. 35-36).

O aspecto decadente do Tritão denuncia o seu estado de abandono, que reflete a crise familiar dos Tallis e, num sentido mais amplo, reflete a decadência da instituição do matrimônio. Apesar da aparente opulência e do esnobismo de Emily e Leon (mãe e irmão de Briony), o estado de abandono é algo generalizado na família. Praticamente abandonada pelo marido infiel, Emily esforça-se para manter as aparências de um matrimônio feliz; mas, acometida de constantes enxaquecas, não consegue administrar a casa e nem sequer cuidar dos filhos, pois "[a] enfermidade a impedia de dar aos filhos tudo que uma mãe devia dar” (p. 84). A ausência da mãe leva Cecilia a assumir os cuidados com Briony e a passar uma ou outra instrução aos empregados, mas ela mesma precisa de atenção: "Cecilia levava bandejas de chá ao quarto da mãe - tão espetacularmente bagunçado quanto o seu - na esperança de desenvolver alguma conversa mais íntima” (p. 25). Porém, os esforços de Cecilia são inúteis, visto que Emily "recostava-se nos travesseiros, com sua expressão inescrutável no rosto, na penumbra do quarto, esvaziando sua xícara num silêncio lânguido" (p. 25). Esta situação agrava-se com a chegada dos primos do norte, que 'abandonados' pelos pais, em processo de divórcio, ficam quase que entregues a si mesmos.

A história de amor entre Robbie e Cecilia desdobra-se metaficcionalmente em dois denouements: um trágico e, paradoxalmente, um feliz. O final trágico relata a morte prematura de Robbie e de Cecilia durante a II Guerra Mundial, ocasionada, em parte, pela intervenção catastrófica de Briony, e reflete a natureza contingente da 'realidade'. O final feliz é inventado pela 'escritora' Briony e a união dos amantes é tornada possível apenas na ficção. A estética metaficcional 
gerencia estes desdobramentos finais, em que elementos antitéticos se encontram em relações dialógicas, provocando a confluência temática do imaginário com o 'real' e da ética com a estética.

A narrativa densamente introspectiva desta passagem parodia a literatura moderna de cunho psicológico, cujos expoentes no contexto mundial são o escritor norte-americano Henry James, a escritora inglesa Virginia Woolf e o escritor irlandês James Joyce. Este rico 'capítulo' da história da literatura ocidental certamente seria incluído numa revisão orientada pelo propósito metaficcional paródico que norteia a estética do romance Atonement. Sabe-se que o tratamento dado à escritura por estes escritores inaugurou uma nova fase do desenvolvimento da narrativa, ainda não experimentado no meio literário até então. Assim, rompendo com os paradigmas convencionais do fazer literário do século XIX, surgiu uma narrativa inovadora caracterizada pela descrição de impressões, percepções e emoções, veiculadas por digressões psicológicas.

Através do uso de técnicas como o monólogo interior e o fluxo da consciência, a arte literária moderna se internaliza, torna-se autorreflexiva e deixa seu legado inconteste na prática da literatura contemporânea. De fato, a influência de James, de Joyce e de Woolf no romance de McEwan é explicitada não apenas através do estilo parodiado, mas também através da temática. A despeito da influência de Virginia Woolf, por exemplo, Peter Childs argumenta que "Atonement também ecoa a recriação de Bourton feita por Clarissa na sua rememoração em Mrs Dalloway (1925), de Virginia Woolf, e seu método de alterar as perspectivas lembra fortemente a escrita de Woolf" (CHILDS, 2006, p.130). Os traços da personagem Clarissa são visíveis em Emily Tallis, particularmente no capítulo seis da primeira parte de Atonement, em que observamos num estilo internalizado as 
impressões de Emily, acompanhando os movimentos das pessoas na casa, quase que telepaticamente.

E, assim, ela permanecia deitada, enquanto a tarde se esvaía. A porta da frente se abrira e fechara. Briony teria saído de mau humor, provavelmente para ficar junto à água, na piscina, ou no lago, ou talvez ela tenha ido até ao rio. Emily ouviu um passo cuidadoso na escada - Cecilia finalmente levando as flores para o quarto de visitas, uma tarefa simples que ela tinha lhe pedido muitas vezes que fizesse naquele dia. Depois, mais tarde, Betty chamando Danny, e o som da carruagem sobre o cascalho, e Cecília descendo para receber as visitas, e logo em seguida, se espalhando pela penumbra, um levíssimo cheiro de cigarro - ela tinha pedido milhares de vezes para que não fumasse na escada, mas Cecilia queria impressionar o amigo de Leon, o que talvez não fosse má ideia. Vozes ecoando no hall, Danny subindo a escada com a bagagem, depois descendo, e silêncio - Cecilia teria levado Leon e o Sr. Marshall até a piscina para tomar ponche que Emily pessoalmente fizera naquela manhã. Ouviu uma criatura quadrúpede descendo a escada - os gêmeos, querendo ir à piscina e logo se decepcionado ao ver que ela estava ocupada (p. 86-87).

É interessante pontuar que todo o romance Atonement caracteriza-se por uma narrativa introspectiva, cuja presença se justifica neste contexto metaficcional, pois a introspecção também assinala a representação do processo cognitivo, próprio da construção do pensamento e do discurso, posto em termos tautológicos. Portanto, a introspecção encontra-se a serviço da estética metaficcional do romance. Ademais, a narrativa introspectiva em Atonement permite a instauração de um modo de caracterização, filtrada pelas mentes das próprias personagens. Particularmente, no caso de Briony, a caracterização surge também vinculada aos comentários autorais ao longo do romance, sinalizando o papel de 'autora' que lhe é atribuído. Um 
exemplo deste processo de caracterização, extraído do capítulo dois, traz informações importantes acerca do caráter de Cecilia e, sob a perspectiva de Cecilia, também é evidenciado o caráter de Robbie.

Ninguém retinha Cecília, particularmente ninguém se importaria se fosse embora. Não era o torpor que a impedia - ficava frequentemente inquieta a ponto de irritar-se. Ela simplesmente gostava de sentir que era impedida de partir, que precisavam dela. De vez em quando se convencia de que estava ali por causa de Briony, ou para ajudar a mãe, ou porque aquela era realmente sua última mais longa estadia em casa e ela lidaria com a situação. De fato, o pensamento de fazer as malas e tomar o trem matinal não a estimulava. Partir por partir. Protelando ali, entediada e acomodada, era uma forma de autopunição mesclada com o prazer, ou a expectativa de prazer; se fosse embora, alguma coisa ruim poderia acontecer ou, pior ainda, alguma coisa boa, alguma coisa que ela não podia perder. E havia Robbie, que a exasperava com sua afetação de distância, e seus planos mirabolantes que ele somente discutia com o pai dela. Eles se conheciam desde os sete anos, ela e Robbie, e a incomodava que ficassem constrangidos quando conversavam. Embora achasse que era culpa mais dele - será que o diploma de primeira classe lhe subira à cabeça? - sabia que isto era algo que devia esclarecer antes de pensar em partir (p. 27).

Como Robbie, Cecilia havia concluído os estudos em literatura na universidade de Cambridge e precisava tomar decisões sobre sua vida pessoal e profissional. Embora Cecilia busque motivos que justifiquem sua estadia com a família, seus pensamentos evidenciam o tédio e a apatia que dominam sua vida, a superficialidade do seu relacionamento familiar e sua preocupação com Robbie. "Ela não podia ficar ali, sabia que devia fazer planos, mas nada fazia” (p. 26). O aparente distanciamento de Robbie a perturba e intensifica sua inquietação. Sua expectativa por algum acontecimento novo e sua relação com Robbie 
parecem ser bons motivos para permanecer um pouco mais com a família. Na verdade, a questão da expectação, apresentada na citação, prepara o leitor para os acontecimentos futuros, mas, de modo lúdico, não deixa claro para qual direção este futuro apontará.

Além disto, esta passagem mostra a introdução gradativa de Robbie na narrativa, que acontece através da ótica de Cecilia. O comentário acerca do grau concedido a Robbie esconde, realmente, a indignação de Cecilia em relação ao tratamento desigual dado aos estudantes do sexo feminino em Cambridge. Pois, neste sentido, os regulamentos internos da instituição, que perduraram até 1948, impunham restrições que impediam Cecilia de receber seu mérito, embora esta tenha conseguido o terceiro lugar nos estudos. Vale ressaltar que há aqui uma crítica sutil à discriminação contra a mulher dentro do sistema educacional inglês, pois "eles realmente não concediam diplomas às mulheres, de modo nenhum" (p. 35).

Um dos aspectos mais notáveis em Atonement diz respeito à relação entre o romance e a carta do editor da Horizon, Cyrill Connolly ${ }^{5}$, a Briony, destacando particularmente a cena da fonte. $\mathrm{Na}$ carta, Connolly elogia a construção de algumas imagens e o modo como os temas da imaturidade e da iniciação na vida adulta são explorados. Porém, ele critica a excessiva influência de Woolf no texto, a falta de desenvolvimento do enredo, atribuída a uma "qualidade estática" (p. 403, grifo do autor) na escrita, apesar de um início promissor. Connolly não questiona o "valor dessa experimentação" do romance psicológico, pois tal procedimento "permite que o escritor mostre seus talentos, mergulhe nos mistérios da percepção, apresente uma versão estilizada dos processos de pensamento, permite que as divagações e imprevisibilidade do íntimo sejam exploradas e assim por diante" (p. 402, grifos do autor). Contudo, ele aponta para o risco de se tropeçar no preciosismo, que pode impedir o movi- 
mento da narrativa para frente. Connolly sugere que uma narrativa fluente cativa a atenção do leitor.

O mais interessante é observar que as recomendações do crítico, feitas na carta, foram 'acatadas' na escrita da primeira parte do romance Atonement. No seu ensaio sobre este romance de McEwan, ao examinar a carta do crítico incorporada na narrativa do romance, Frank Kermode (apud CHILDS, 2006, p. 133) conclui: "[a] implicação é que o romance atual é uma expansão daquele primeiro trabalho". $\mathrm{O}$ comentário de Kermode ressalta a correlação e, sobretudo, a influência da carta do crítico no romance. Isto significa que a primeira parte do romance, que contém as duas versões da cena da fonte, é elaborada para ser compreendida como uma reconstrução ampliada da novela Two figures by a fountain, de Briony Tallis. Ademais, ao comentar sobre as várias versões do seu romance, Briony afirma ser "[a] versão mais antiga, [aquela de] janeiro de 1940 [...]" (p. 476). Então, entendemos que a novela Two figures by a fountain é a primeira versão do romance de Briony, o que reitera a conclusão de Kermode.

Além disto, na última parte de Atonement, há a revelação de Briony sobre sua decisão de narrar seu 'crime': "[...] da segunda versão em diante, decidi descrevê-lo. Considerei ser minha obrigação não disfarçar nada - os nomes, os lugares, as circunstâncias exatas coloquei tudo no texto como se fosse um relato histórico" (p. 476-7). Segundo Briony, a segunda versão do seu romance data de "junho de 1947" (p. 476), o que daria a ela vinte e cinco anos de idade. O fato é que os desdobramentos narrativos, provocados pela metaficção, permitem argumentar, após a leitura da carta de Connolly, que a primeira parte do romance Atonement pode ser lida como uma das versões do romance de Briony, 'enxertada' no romance de McEwan.

No que concerne especificamente à cena da fonte, um paralelo entre a carta de Connolly e o romance Atonement desnuda as al- 
terações feitas no texto, supostamente a partir dos comentários do crítico. Connolly primeiramente lamenta a ausência de um exemplo da escrita da menina-escritora na novela Two figures by a fountain. McEwan começa o romance Atonement com uma peça teatral escrita por Briony aos treze anos, da qual se tem um fragmento do prólogo, logo nas primeiras páginas. Connolly comenta sobre a improbabilidade de se usar um vaso Ming para colher água na fonte e o vaso usado é "de autêntica porcelana Meissen, a obra do grande artista Höroldt, que o pintara em 1726" (p. 30), descrito e historiado por Cecilia no Capítulo II. Também, a descrição da fonte é corrigida, conforme a explicação dada por Connolly de que escultura Triton de Bernini se localiza na Piazza Barberini e "não na Piazza Navona" (p. 404, grifo do autor). Connolly observa que a jovem entra vestida na fonte, na novela de Briony, e Cecilia tira as roupas de cima nas duas versões da cena da fonte em Atonement, o que pode trazer implicações morais. Connolly sugere que a menina devia ignorar a existência de um vaso quebrado, o que pode contribuir para confundir a menina, na sua interpretação da cena. Para impulsionar o mistério no enredo, Connolly sugere que a jovem mergulhe na fonte e assim acontece em Atonement. Talvez, atentando para a sugestão de se utilizar um modo mais econômico de escrita, a versão do personagem masculino é suprimida. A versão da menina na janela é transferida para um segundo momento e a disputa pelo vaso nesta segunda versão é omitida, o que favorece a fantasia da menina (Briony) contra o homem (Robbie) em Atonement; pois desconhecendo a existência do vaso, a menina (Briony) fica livre para imaginar a motivação dos gestos e das ações do personagem masculino (Robbie). Connolly, ainda, questiona a ineficiência no desenvolvimento da cena da fonte, trazendo as seguintes reflexões: 
Se esta menina compreendeu de modo tão equivocado a estranha cena que se desenrolou diante de seus olhos, ou ficou tão intrigada com ela, de que maneira este fato poderia afetar as vidas dos dois adultos? A menina poderia intervir entre eles de modo desastroso? Ou os aproximaria, de propósito ou por acaso? Não poderia ela, de modo inocente, os expor de alguma maneira, diante dos pais da moça, por exemplo? Certamente eles não aprovariam uma ligação entre sua filha mais velha e o filho da arrumadeira. O jovem casal poderia vir a utilizar a menina como mensageira? (p. 403-404, grifos do autor)

A relevância destas ponderações está espelhada na própria narrativa de Atonement, que se desenvolve a partir da cena da fonte. Observamos que as cogitações de Connolly são 'adotadas' integralmente no romance, de modo que o enredo se desenvolve a partir da tensão elaborada pela intervenção desastrosa de Briony, que serve de mensageira para Robbie e expõe o casal a uma situação difícil, obrigando-os à separação; mas, intencionalmente, a escritora Briony os aproxima na sua ficção. Connolly ainda aconselha Briony acerca da recepção da narrativa, lembrando que "[s]eus leitores mais sofisticados podem muito bem conhecer as mais recentes teorias da consciência de Bergson, mas estou certo de que eles guardam um desejo infantil de ouvir uma história, de ficar em suspense, de saber o que acontece" (p. 404, grifos do autor). Ressaltamos que as teorias da consciência de Henri Bergson postulam a dinamicidade da consciência, a qual se caracteriza por constante mudança, com a agregação de impressões presentes às lembranças passadas.

Sem dúvida, estas teorias influenciaram a estética do modernismo, incidindo na construtividade do romance psicológico. Connolly reconhece a importância das teorias bergsonianas, mas sabiamente adverte Briony sobre o efeito da narrativa excessivamente introspectiva e sobre a necessidade do público por uma história bem contada; 
em suas palavras: “[u]m desenvolvimento é necessário” (p. 402, grifos do autor). Neste sentido, as palavras de Connolly denunciam uma crítica a possíveis preciosismos praticados no modernismo. Aliás, esta crítica é esperada por meio do propósito paródico de revisão do cânone literário, presente em Atonement. Entretanto, a inserção de elementos reais na ficção, vista nesta mesma carta, já sinaliza as marcas do pós-modernismo no romance.

O conflito de classe, também mencionado por Connolly, é uma questão crucial no desenvolvimento narrativo de Atonement. Por envolver a tratamento com o outro, o conflito de classes associa-se à discussão da ética da alteridade e, semelhante ao tema da guerra, perpassa o romance, envolvendo todas as personagens. Aliás, no âmbito privado, as tensões sociais são construídas através das diferenças de classe entre três segmentos: os Tallis, seus familiares e os empregados. Os Tallis pertencem a uma classe média alta, embora sua descendência do lado paterno tenha origens na classe popular. $\mathrm{Na}$ verdade, Cecilia tenta traçar a árvore genealógica da família e descobre que

[...] do lado paterno, antes de seu bisavô abrir sua humilde loja de ferragens, os ancestrais estavam irreparavelmente afundados num pântano de trabalhadores rurais, com mudanças de sobrenomes suspeitas e confusas entre os homens e casamentos informais jamais registrados nas paróquias rurais (p. 26).

Apesar desta origem social, o esnobismo caracteriza alguns membros da família Tallis, como Emily e Leon, de modo que mesmo a benevolência de Jack Tallis, ao doar o bangalô a Grace Turner (mãe de Robbie) e custear as despesas com a educação de Robbie, é considerada um capricho de Jack. Para Emily, "na realidade Robbie era um dos hobbies de Jack, a prova viva de algum princípio iguali- 
tário que ele seguia há anos" (p. 193). A oposição de Emily à decisão do seu marido de financiar os estudos de Robbie tinha por motivo a intolerância à classe popular. Ela não suportava a possibilidade da inserção de um intruso na sua classe social, pois afinal a educação iria proporcionar "[a] elevação de Robbie" (p. 194). Emily também julgava aquilo "uma intromissão e uma injustiça com Leon e as meninas" (p. 194). Sua frase costumeira sobre este assunto é clara: “"[n] ada de bom virá daí"' (p. 194).

O mesmo olhar esnobe pode ser percebido em Leon. Ao comentar com Cecilia que havia convidado Robbie para o jantar, Leon desfere sua zombaria: "Você acha que ele não pode segurar uma faca e um garfo"' (p. 67). Afinal, a etiqueta à mesa não é esperada daqueles de classe popular. Numa das cartas a Robbie, ao explicar sobre sua decisão de se separar definitivamente da família, Cecilia escreve: "[a] gora que me separei deles, estou começando a entender o esnobismo que estava por trás da estupidez deles' (p. 267). Na verdade, o esnobismo esconde a hipocrisia, com a qual Emily é conivente, pois finge aceitar as mentiras do marido infiel, para manter o status quo:

Se essa falsidade era hipocrisia convencional, ela tinha de admitir que a hipocrisia tivesse sua utilidade. Ela tinha fontes de contentamento em sua vida - a casa, o parque e, acima de tudo, os filhos - e para preservá-las ela não questiona Jack. [...] Aquelas mentiras constantes, embora não fosse amor, era uma forma de atenção; certamente ele deveria gostar dela para inventar mentiras tão elaboradas e durante tanto tempo. A falsidade de Jack era uma forma de tributo à importância de seu casamento (p. 189).

Nesse caso, o fingimento passa a ser uma forma de camuflar a crise matrimonial, em prol da manutenção de uma situação conveniente. Emily representa o segmento burguês da sociedade, que, em- 
bora esteja em franca decadência, faz uso de armas, como a mentira e a hipocrisia, para sustentar sua aparência social e conservar-se no poder. Agravando a crise familiar, há a questão do divórcio da irmã mais nova de Emily e seu escandaloso romance com um homem da rádio, resultando no envio das crianças para a casa dos Tallis, como "refugiados de uma verdadeira guerra civil familiar" (p. 9). Além de carregarem o opróbrio de serem filhos de pais divorciados, esta condição de 'penetras' no círculo familiar dos Tallis os coloca em posição inferior. Por isto, os primos do norte "agora, como convidados na sua [de Briony] casa, acreditavam que lhe deviam um favor. O que era pior ainda, Lola deixava claro que também ela estava agindo por obrigação" (p. 15).

Entretanto, o cerne do conflito de classe em Atonement reside no relacionamento entre a jovem de classe média alta (Cecilia) e o filho da arrumadeira (Robbie). Além disto, a temática do conflito social explora a crítica à burguesia inglesa, tipificada nos Tallis, e a sua intolerância à classe popular ou a qualquer tentativa de ascensão social desta, especialmente via casamento, o que é visto como petulância e oportunismo. A alta sociedade não tolera o que considera transgressões e esse conceito transparece nas palavras de Briony, exemplificadas na citação abaixo. Ao observar a cena da fonte da janela do seu quarto, Briony interpreta os gestos de Robbie como

[u]ma proposta de casamento: Briony não estaria surpresa. Ela mesma tinha escrito um conto no qual o lenhador humilde salvou uma princesa de afogamento e terminou casando-se com ela. O que se apresentava aqui encaixava bem. Robbie Turner, filho único de uma humilde arrumadeira, pai desconhecido, Robbie, cujos estudos haviam sido financiados pelo pai de Briony, desde a escola até a universidade, que antes queria ser paisagista e agora queria estudar medicina, tinha a 
audácia da ambição para pedir a mão de Cecília. Fazia todo o sentido. Essas violações de fronteiras eram assuntos dos romances cotidianos (p. 48).

Sob a ótica de Briony, o conflito de classes é ironicamente abordado, ressaltando a distância social entre Robbie e Cecilia. A demanda crítica advém da metaficção, pois o texto parodia a temática comum a uma literatura melodramática e a sutileza irônica é evidenciada pela exposição da condição social de Robbie num contexto ambíguo. Também, a escolha de palavras, como nas expressões "audácia da ambição" e "violações de fronteiras", denota a carga irônica e crítica em relação ao preconceito e às convenções sociais. Sob esta ótica, a condição social de Robbie e a moral duvidosa, do lado materno, o desqualificam como pretendente de Cecilia. A decisão de Robbie de cursar medicina, subsidiado pelo pai de Briony, é posta como uma presunção ou um capricho. Sua ambição é vista como uma insolência. Sua proposta de casamento feita a Cecilia é concebida como uma violação às convenções sociais. Além disto, é interessante observar que a familiaridade de Briony com a literatura melodramática é o que lhe dá suporte para fazer a 'leitura' da cena. O texto denuncia que a fantasia é o parâmetro de julgamento da 'realidade' para Briony. Desta forma, o conflito entre ficção e realidade é explorado nesta passagem, explicitando suas implicações no processo de decodificação do ato de leitura. Como leitora, Briony faz a interpretação da cena e constrói um sentido em conformidade com seu conhecimento prévio, resultando numa confusão, ou numa distorção da 'realidade'.

Neste contexto, encontramos, ainda, a crítica ao sistema social hierárquico, que considera aqueles de posição elevada portadores de conduta ilibada e reputa as classes populares a propensão às ações vis. Por isto, ninguém suspeita que Paul Marshall, o milionário do chocolate, é o 'molestador' de Lola; sua origem social lhe garante 
proteção perante a sociedade; enquanto que a acusação contra Robbie é facilmente aceita pelos Tallis, apesar das evidências contrárias e do absurdo testemunho de uma menina, reconhecidamente inclinada à fantasia. Também, Danny Hardman, o filho do empregado da casa, é alvo da suspeita de todos. Para aumentar a tensão, ou talvez para confundir o leitor, Cecilia vê Danny rondando por perto das crianças e pensa que "[t]alvez ele estivesse interessado em Lola. Estava com dezesseis anos e certamente não era mais um menino" (p. 61). O fato é que parece que Cecilia acredita que Danny poderia ter atacado Lola; pois, numa carta a Robbie, ela comenta: "Quando Hardman decidiu acobertar Danny, ninguém da minha família quis que a polícia o interrogasse com as perguntas óbvias. A polícia tinha você para processar" (p. 267).

Esta questão é retomada no final do romance de Briony, por ocasião da visita de Briony a Cecilia e Robbie em Balham. Durante a conversa, Robbie exige de Briony uma retratação pública e dá a seguinte ordem: "E, se você puder se lembrar de qualquer coisa a respeito de Danny Hardman, onde ele estava, o que ele estava fazendo, a que horas, quem mais o viu - qualquer coisa que possa questionar o álibi dele, então queremos saber" (p. 446). Ao que parece, Robbie e Cecilia também adotam o mesmo pensamento estereotipado da sociedade. $\mathrm{O}$ aspecto perturbador aqui é que o leitor é informado, pela própria Briony, que esta visita a Balham nunca aconteceu: “[...] eu nunca os vi naquele ano" (p. 478). Portanto, a conversa foi inventada. O conflito entre o real e o imaginário se imbrica mais uma vez com o conflito de classes, problematizando a construção do sentido do texto. A leitura exige uma redecodificação, com a alteração das 'evidências'. O distanciamento da 'escritora' Briony, aos setenta e sete anos, faculta ironicamente a Robbie a adoção do pensamento hegemônico da burguesia, como uma forma de criticar o antagonismo 
social e seu devastador poder de persuasão. Todavia, capturar esta mensagem exige do leitor uma releitura da caracterização de Robbie no início desta passagem literária, em que sua tendência política esquerdista é referida por Cecilia.

\section{A segunda versão da cena da fonte no romance}

Por ocasião de uma entrevista de Ian McEwan a Adam Begley, datada de 2002, o assunto volta-se para a questão do ponto de vista de Briony nos primeiros capítulos de Atonement, "quando ela é ainda uma menina precoce com uma comichão para escrever e um gosto perigoso pelo melodrama" (apud ROBERTS, 2010, p. 93). Ao ser perguntado sobre a possibilidade de tratar-se do retorno ao tema a visão de "mundo da perspectiva de uma criança", Ian McEwan afirma:

Parece ser uma imersão muito mais profunda. Não querendo chocar as pessoas ou admitir que o grotesco permita uma liberdade muito maior em termos psicológicos. É sempre um problema fazer ficção como se fora de crianças - o ponto de vista restrito pode tornar-se sufocante. Minha intenção era retratar a mente de uma criança enquanto extraía os recursos da linguagem complexa de um adulto - como James fez em What Maisie knew. Não queria as limitações de um vocabulário como o de crianças. Joyce faz assim nas páginas de abertura de $A$ portrait of the artist as a young man. Todos nós tentamos imitar isto. Ele mantém você dentro do universo sensório e linguístico de um menininho, e é um fragmento mágico que ilumina - e, então se vai, exatamente como a própria infância. Joyce move-se, a linguagem expande-se. Meu caminho por este problema foi fazer de Briony minha 'autora' e permitir que ela descrevesse o eu da sua infância de dentro para fora, mas na linguagem de uma romancista madura (apud ROBERTS, 2010, p. 93-94). 
Em poucas palavras, McEwan aborda questões centrais do romance Atonement, como o tema, o ponto de vista, o estilo e o desdobramento estrutural, trazendo revelações acerca da intencionalidade autoral, da escolha linguística, da elaboração da perspectiva e da influência intertextual na construção de sua narrativa. É interessante observar que McEwan admite ter conferido a 'autoria' a Briony como uma solução para superar os limites decorrentes da linguagem específica de uma criança. Porém, questões como a focalização e a instância narrativa tornam-se intensamente problematizadas no seu romance. Sem dúvida, o manejo audacioso destes recursos constitui uma complexa estratégia na elaboração da metaficcionalidade do romance Atonement.

A paródia e a metaficção adensam sobremaneira a polifonia já existente no romance Atonement. Certamente esta obra que se desdobra por dentro de si mesma favorece a multiplicação de vozes e de níveis narrativos no seu universo ficcional. Devido ao desdobramento estrutural, esta passagem da fonte extraída do final do capítulo três, particularmente, merece um exame cuidadoso:

Poderia se imaginar correndo agora para seu quarto, tomando um bloco de papel pautado e a caneta-tinteiro de baquelita marmorizada. Poderia ver as frases simples, os símbolos telepáticos se acumulando, fluindo da ponta da pena. Poderia escrever a cena três vezes, de três pontos de vista; sua excitação era devido à expectativa de liberdade, de livrar-se da luta enfadonha entre bons e maus, heróis e vilões. Nenhum desses três era mau, nem era particularmente bom. Ela não precisava julgar. Não precisava haver uma moral. Precisava apenas mostrar mentes separadas, tão vivas quanto à dela, pelejando com a ideia de que outras mentes eram igualmente vivas. Não era somente o mal e as tramoias que tornavam as pessoas infelizes, era a confusão e o mal-entendido; sobretudo, era a incapacidade de apreender a 
simples verdade de que as outras pessoas são tão reais quanto você. E somente numa história você podia adentrar estas mentes diferentes e mostrar como elas tinham o mesmo valor. Essa era a única moral que uma história precisava ter.

Seis décadas depois, ela descreveria como, aos treze anos de idade, tinha atravessado, com seus escritos, toda uma história da literatura, começando com as histórias baseadas na tradição folclórica europeia, passando pelo drama com intenção moral simples, até chegar a um realismo psicológico imparcial que descobrira sozinha, numa manhã específica, durante uma onda de calor em 1935. Ela teria perfeita consciência da extensão da sua automitificação e daria ao seu relato um tom irônico ou herói-cômico. Sua ficção seria conhecida por sua amoralidade, e, como todos os escritores pressionados pela mesma pergunta, ela se sentiria obrigada a produzir uma passagem na história, um enredo de sua autoria, que contivesse o momento em que ela própria se reconheceria na história. Sabia que não era correto se referir a suas peças no plural, que seu escárnio a distanciaria da criança séria e pensativa, e que não seria aquela manhã tão distante o que estava lembrando tanto, mas os relatos posteriores que havia feito dela. Era possível que a contemplação de um dedo dobrado, a ideia insuportável de outras mentes e a superioridade das histórias sobre as peças fossem pensamentos que tinha lhe ocorrido em dias diferentes. Sabia também que o que quer que haja realmente acontecido ganharia sua importância a partir de sua obra publicada, e não teria sido lembrado se não fosse por ela (p. 51-52).

A pertinência da citação desta passagem decorre do fato de que nela concentra-se uma espécie de síntese do projeto ideológico da obra: o complexo debate entre ética e estética, regido pela paródia numa escritura metaficcional. A revisitação paródica do cânone literário é explicitada pela referência à travessia da 'escritora' em "toda uma história da literatura”. A dramatização do ato de escrita expõe a ficcionalidade do texto, rompendo com a escritura ilusionista, como 
por exemplo: "Poderia ver as frases simples, os símbolos telepáticos se acumulando, fluindo da ponta da pena". A feitura textual é desnudada também pela argumentação teórica e crítica, incorporada no texto, a exemplo dos fragmentos: "Poderia escrever a cena três vezes, de três pontos de vista" e "Ela teria perfeita consciência da extensão da sua automitificação e daria ao seu relato um tom irônico ou herói-cômico". Destacamos, ainda, questões como a polifonia, a autoridade textual: sua postura e consciência, o ponto de vista e a exploração de temas fundamentais no romance, como a autojustificação e a alteridade.

Percebemos que a Parte I do romance assinala uma narrativa em terceira pessoa, oriunda de uma instância onisciente e anônima, que, em relação ao nível narrativo, classifica-se como um narrador extradiegético, pois conta a história da qual não faz parte (GENETTE, s.d, p. 247). A voz desta instância narrativa onisciente, em algumas partes, com onisciência seletiva múltipla ${ }^{6}$, é perceptível na enunciação e construída pelo uso dos verbos no futuro do pretérito, que indicam conjecturas, suposições e probabilidades. O distanciamento espaço-temporal, desta voz que narra, possibilita a fluidez do imaginário e a logicidade do enunciado, que naturalmente avança no tempo ("Seis décadas depois"), como acontece nos processos mentais, sem comprometer a recepção da mensagem, nem se configurar visivelmente como "grotesco" (apud ROBERTS, 2010, p. 94), usando a adjetivo empregado por McEwan. Este narrador em terceira pessoa orquestra a narrativa, delegando voz às personagens, para que a consciência do outro se torne visível na narração: "Precisava apenas mostrar mentes separadas, tão vivas quanto a dela, pelejando com a ideia de que outras mentes eram igualmente vivas" (p. 51). Contudo, a voz deste narrador extradiegético também se faz 'ouvir', no fragmento citado, como a 
instância narrativa madura, que detém o conhecimento abalizado de literatura sobre a questão do maniqueísmo e da moralidade na ficção, bem como a percepção clarividente sobre a importância da alteridade no relacionamento humano.

A multiplicidade de vozes já é algo esperado no romance polifônico, mas em Atonement a relação dialógica entre as vozes pode também se efetuar em dimensões abertas pelo agenciamento da metaficção, o que permite a sobreposição de vozes e de focalizações. Observemos, por exemplo, o seguinte fragmento da citação em baila: "Agora não restava nada da cena muda ocorrida junto à fonte senão o que sobrevivia na memória, em três lembranças separadas que se sobrepunham" (p. 52). Portanto, a possibilidade de sobreposições de vozes e de focalização é fato comprovado na escrita metaficcional contemporânea. Contudo, esta sobreposição manifesta-se através dos desdobramentos narrativos e do jogo de ambiguidades, nos níveis estrutural e linguístico, e concretiza-se no âmbito hermenêutico, por meio da construção de sentido, efetuada pelo leitor. Conforme Hutcheon (1980, p. 141, grifo da autora), “[o] leitor da ficção é sempre uma presença mediadora e ativa; a realidade do texto é estabelecida pela sua resposta e reconstituída pela sua participação efetiva" . Porém, na obra metaficcional, "paradoxalmente o texto também demanda que ele [o leitor] participe, que se engaje intelectual, imaginativa e afetivamente na sua co-criação" (HUTCHEON, 1980, p. 7). Aliás, Hutcheon (1980, p. 49) também observa que, em textos metaficcionais, "a tarefa do leitor torna-se imensamente difícil e litigante, à medida que ele separa os vários fios narrativos". Evidentemente, a decodificação das obras metaficcionais é complexa e exige mais aptidão e conhecimento do leitor.

Implícita na citação, há a questão da autojustificação, que requer uma análise criteriosa, devido à sua importância na narrativa de Ato- 
nement. Numa entrevista com Jonathan Noakes, McEwan afirma que em Atonement, "[e]u queria jogar com a noção da narrativa como uma forma de autojustificação, do quanto de coragem envolve se contar a verdade para si mesmo" (apud ROBERTS, 2010, p. 86). No final do romance Atonement, Briony confessa: "[m]inha tarefa durante esses cinquenta e nove anos terminou" (p. 476). A tarefa que Briony se imbuiu de executar foi a reparação do seu 'crime', mencionada no final da Parte III de Atonement, através da palavra 'atonement' (reparação): “[e]la sabia o que era requerido dela. Não simplesmente uma carta, mas uma nova versão, uma reparação [atonement], e ela estava pronta para começar" (p. 451). Portanto, considerando a ótica da 'escritora' Briony, na sua maturidade, a narrativa pode ser interpretada como sua autojustificação, pois nela se explica a causa do seu 'crime', seu método de reparação e sua 'possível inocência'.

Neste sentido, examinemos, pois, as palavras da citação: "Não era somente o mal e as tramoias que tornavam as pessoas infelizes, era a confusão e o mal-entendido; sobretudo, era a incapacidade de apreender a simples verdade de que as outras pessoas são tão reais quanto você” (p. 51). Assim sendo, o teor da questão está na incapacidade de discernir o real do imaginário, tema parodiado do romance Northanger Abbey, de Jane Austen, e expresso na epígrafe de Atonement. Em outras palavras, Briony se justifica, alegando que, não sendo capaz de distinguir o real do imaginário, provocou a infelicidade de outros e toma por testemunhas as mentes daqueles envolvidos no fato, incluindo as próprias vítimas, para livrar-se do sentimento de 'culpa' que a condena, mas a única maneira de assim fazer é através da ficção, "[e] somente numa história você podia adentrar estas mentes diferentes e mostrar como elas tinham o mesmo valor. Essa era a única moral que uma história precisava ter" (p. 51). Sem dúvida, isto diz respeito ao entrelaçamento entre estética e ética. É relevante des- 
tacar que do imbricamento conflitante entre estética e ética, a ética da alteridade é apontada como a saída da crise.

A relação dialógica com o outro e a questão da igualdade são perceptíveis na citação de Atonement, que compõe esta versão da cena da fonte. É perceptível que há um tribunal aberto no nível do universo ficcional, cujo julgado e julgador é a própria Briony e isto esclarece a necessidade das múltiplas focalizações e da escritura novelística, para apropriadamente veiculá-las. O processo de autojustificação é construído por meio dos comentários autorais, da multiplicidade de vozes na narrativa e das múltiplas focalizações, que compõem a primeira parte do romance. Inclusive, a transferência do lócus de caracterização para as mentes das personagens parece ser feita para conferir credibilidade a este processo de autojustificação de Briony. Esta observação é reiterada pela comunicação dialógica, expressa na seguinte citação "[...] a gente tinha de se medir por outras pessoas - realmente não havia outro critério. De vez em quando, sem intenção alguma, alguém lhe ensinava algo sobre si mesma" (p. 150). Este critério de autoconhecimento e de julgamento de uma pessoa, postulado nesta citação, encontra-se certamente no bojo da discussão acerca da alteridade, norteamento ético do romance Atonement.

\section{Primeira versão da cena da fonte no filme}

Esta sequência caracteriza-se pelo uso alternado da câmera objetiva e da câmera subjetiva ${ }^{7}$, criando um jogo de imagens, que permite ao espectador ora ver pelos olhos de Briony, ora ver pela narração do narrador. A sequência inicia com Briony movendo-se em direção à janela, atraída pelo som de um inseto. A imagem passa de plano médio ${ }^{8}$ para um close up do rosto de Briony. Após um corte seco $^{9}$, entra a câmera subjetiva anunciando, num close up, a presença 
de uma abelha, tentando atravessar o vidro. Em seguida, outro close up do rosto de Briony mostra seu esforço para ajustar o olhar sobre o que vê através da janela. Uma tomada em plano geral, a plongée ${ }^{10}$, exibe a cena se desenvolvendo junto à fonte, localizada no centro de uma vasta área de gramado verde. Através do canal visual, vemos Cecília despindo-se, aparentemente sob o comando de Robbie.

A câmera agora é posicionada num ângulo frontal, de dentro do quarto para as janelas, exibindo Briony de costas e ajoelhada sobre o sofá, na sua posição de voyeur. O voyeurismo está ligado à escopofilia ${ }^{11}$ (o prazer de olhar), atribuída ao espectador, e diz respeito a um dos prazeres próprios do cinema. De fato, Briony assume temporariamente o papel de espectador. Ademais, a conjunção do olhar da personagem com o olhar do espectador gera um desdobramento estrutural-diegético, uma espécie de um filme dentro do filme, ou melhor, a sequência dentro de uma sequência. Neste sentido, constata-se uma representação da essência da arte cinematográfica: sua feitura, vista na fragmentação, e sua recepção, apontada na espectatorialidade.

O novo posicionamento da câmera no filme permite que vejamos a reação de Briony, após presenciar a irmã despindo-se em plena luz do dia, diante de Robbie. Briony se vira e senta no sofá, esboçando surpresa e horror através de um som gutural, para lentamente voltar à janela e prosseguir com a observação. A partir deste momento, a cena se desenrola com a alternância entre a câmera objetiva e a câmera subjetiva. E, finalmente, a sequência fecha com a imagem do close up do rosto de Briony. Esta técnica aliada ao uso do corte seco e da intercalação dos close ups do rosto de Briony, que permeiam toda a sequência, têm a finalidade de denunciar a percepção que Briony tem da cena da fonte, pois tal percepção é crucial para o desenvolvimento da narrativa. Portanto, a leitura que Briony faz da cena da fon- 
te é transposta para a linguagem cinematográfica basicamente por meio da montagem, dos close ups e da mise en scène da atriz.

\section{Segunda versão da cena da fonte no filme}

A adaptação desta versão da cena da fonte aproxima-se muito da passagem literária. Contudo, um olhar comparativo entre o romance e o filme chama atenção para a inversão das versões da cena da fonte. No filme, a versão sob a ocularização ${ }^{12} \mathrm{em}$ Briony antecede a versão sob a ocularização em Cecilia. A inversão das versões incide obviamente sobre a recepção do filme, uma vez que o espectador é obrigado a fazer uma releitura da cena, à luz das informações introduzidas na segunda versão (sob a ocularização em Cecilia). Consequentemente, com o acesso a mais informação, o olhar do espectador dissocia-se do olhar de Briony, o que intensifica o suspense e a tensão à medida que a história se desenrola. A narrativa profundamente introspectiva é transposta para o filme através da mise en scène da atriz, que adota uma atitude pensativa durante toda a primeira parte da sequência. Os pensamentos de natureza descritiva de Cecilia, veiculados na narrativa literária, são visualizados nas imagens. Porém, alguns de teor mais psicológico são verbalizados, de modo condensado, no diálogo com Robbie. Nesta sequência, a combinação de técnicas cinematográficas, como o plano geral, o close up, o enquadramento e o campo e contracampo ${ }^{13}$, contribui para construir a metaficcionalidade do texto fílmico.

A abertura da sequência mostra Cecília correndo no bosque com um ramalhete de flores na mão. Numa tomada em plano médio, a câmera faz um travelling ${ }^{14}$ lateral, acompanhando os movimentos de Cecilia, tendo no canal sonoro os sons da natureza, o som da respiração ofegante de Cecília e uma música cadenciada, que se harmo- 
174 Lucia Fatima Fernandes Nobre, Lugares/olhares des-locados e a ...

niza ao ritmo dos passos da personagem. Após um corte seco, surge na tela o close up do rosto de Briony. A imagem é congelada em duas posições: olhando para baixo, para marcar o seu posicionamento de voyeur, assistindo à cena da fonte da janela do quarto, no andar superior da casa; e olhando para frente, como que encarando a câmera, o que denota "a perversão da linguagem clássica" (AUMONT; MARIE, 2007, p. 216), pois faz transparecer o discurso fílmico. O congelamento da imagem causa a suspensão temporal e acusa a presença do fotograma, exibindo metaficcionalmente a construção do tecido fílmico. Outro corte dá continuidade à sequência com a imagem de Cecilia correndo no bosque. Neste momento a câmera mantém-se em plano médio, com enquadramento lateral, e move-se ora para cima, ora para baixo, focando a parte superior ou a parte inferior do corpo de Cecilia, como que buscando o ângulo de filmagem. Trata-se, assim, de um recurso metaficcional que subverte o padrão ilusionista, pois denuncia a manejo de um aparato cinematográfico.

Agora, a cena é tomada na cozinha da casa e a câmera está em enquadramento frontal e em plano médio, mas, do lado direito da tela, em primeiro plano, vemos Grace Turner, tirando um bolo da forma sobre uma mesa, que já contém outros dois bolos, e, do lado esquerdo da tela, acentuando a profundidade de campo, surge Cecilia, trazendo o ramalhete nas mãos. O destaque dado a Grace nesta sequência é uma adição inventiva do diretor, cuja relevância se justifica pelo papel de Grace na narrativa e sua associação a Cecilia, particularmente após a prisão de Robbie. Cecilia atravessa a cozinha, passa ao lado da câmera, que se move para filmar Cecilia de costas e captura o momento em que Cecilia toca levemente, com a mão esquerda, no umbral da porta da cozinha. O canal sonoro faz a transição entre os quadros e ouve-se a voz dos gêmeos, pedindo a Cecilia para ir nadar. Então, a câmera mostra, em plano geral, o hall, com 
enquadramento em diagonal em relação ao centro do objeto focal. Trata-se de um ambiente localizado no centro da casa, cujas paredes são forradas por madeira no tom marrom escuro. O hall é circulado por colunas de madeira que sustentam o mezanino. A iluminação indireta, possivelmente oriunda de uma claraboia, cai sobre uma mesa redonda, que fica no centro do hall. Os gêmeos, já vestidos com roupas de banho, estão correndo ao redor da mesa, quando Cecilia entra no ambiente, dando-lhes permissão para irem à piscina, com a recomendação para não nadarem na parte funda. Cecilia atravessa o hall, seguida de perto pelos gêmeos, muito ativos, que, entusiasmados, saem de cena. A câmera fixa acompanha os passos de Cecilia, que entra num pequeno corredor e vira à esquerda, adentrando noutro ambiente, que é a sala de estar.

Em contraste com o hall, predomina na sala uma intensa luminosidade, construída a partir da incidência constante da luz ambiental, da suavidade das cores claras do papel de parede e da tonalidade dos objetos que compõem o cenário. Agora, em plano médio, a câmera mostra Cecilia caminhando pela sala de estar em direção a um vaso de porcelana, posto sobre um órgão, no canto da sala. Cecilia coloca as flores no vaso e ajeita o arranjo. Vemos a imagem, em diagonal, do close up do rosto de Cecilia, examinando, pensativa, $\mathrm{o}$ arranjo de flores. Cecilia posiciona-se de frente para a câmera e baixa os olhos. A câmera segue o movimento dos olhos de Cecilia e foca sobre as cordas do órgão. Cecilia puxa uma corda do órgão e a música suave que a acompanhava desde sua entrada na cozinha é bruscamente interrompida. Na realidade, o toque da corda suspende o som musical e o canal sonoro passa a reproduzir apenas os ruídos ambientais e a pista de registro dos sons fonéticos das falas. É importante observar que a música volta a ser ouvida somente no final da sequência, quando Robbie toca na água, num gesto simbólico do 
desejo de afagar o corpo da amada, o que cria um desdobramento imagético pelo espelhamento ${ }^{15}$.

A tomada, agora em plano médio, mostra Cecilia dirigindo-se ao sofá da saleta anexa. À medida que Cecilia caminha, afasta-se da câmera, abrindo espaço para uma visão geral do ambiente, de modo que podemos observar que a sala é circulada por janelas, que dão para o pátio. A câmera, em diagonal, exibe quando Cecilia senta-se no sofá, olha para fora, pela janela lateral, e tira uma sandália, que cai sobre o assoalho, provocando um barulho. Então, um close up do rosto de Cecilia mostra sua inquietação, enquanto ela tira a outra sandália e olha novamente para fora. Após um corte, vemos, emoldurada pela janela, uma imagem do pátio, com Robbie sentado, de costas, na escadaria; ao fundo, encontra-se o gramado verde com árvores esparsas ao longe. $\mathrm{O}$ emolduramento fragmenta a textura fílmica, traçando a representação de um fotograma. Contudo, neste caso, a impressão de profundidade não suprime a bidimensionalidade da imagem, mas traduz a abertura para outras dimensões: a dimensão espaço-temporal e a dimensão subjetiva do olhar de Cecilia. Em seguida, a câmera faz outro close do rosto de Cecilia ainda olhando de lado, quando ouvimos o som da outra sandália caindo, e Cecilia levanta-se do sofá.

O jogo entre angulação, enquadramento e espelhamento constrói um interessante desdobramento de imagens, quando Cecilia, com o vaso de flores nas mãos, se olha no espelho da sala de estar. A câmera está posicionada na altura do ombro de Cecilia, mas enquadrada na diagonal à esquerda, dando centralidade à imagem refletida no espelho, que chama atenção pela sua nitidez e pelo seu posicionamento no fundo do quadro. $\mathrm{O}$ espelho, centralizado na tela, divide a imagem em três porções - a famosa regra de três - porém, aqui usada para a construção da metaficcionalidade do filme, pois resul- 
ta num desdobramento imagético no mesmo fotograma. Na porção direita da imagem, em primeiro plano, vemos a imagem desfocada das costas de Cecilia e, na porção esquerda, há a imagem desfocada de vários objetos, delineada por uma coluna bem no canto esquerdo do quadro.

Completa esta construção imagética metaficcional, a suspensão de movimento, causada pelo congelamento momentâneo da imagem, que exibe o fotograma como uma fotografia, cuja profundidade de campo é explicitamente construída pelo uso do espelho. Cecilia ajeita o cacho do cabelo, olha para o lado, muito pensativa, e sai da frente do espelho. Em seguida, Cecilia vai ao encontro de Robbie na escadaria do pátio, levando o vaso de flores e pede-lhe um cigarro. Em plano médio, a câmera mostra Robbie sentado na escadaria, enrolando um cigarro. Observamos que a tomada em diagonal cria a impressão de profundidade, exibindo a balaustrada que compõe a fachada da casa. Robbie e Cecilia começam a descer a escadaria do pátio, enquanto iniciam uma conversa, focados pela câmera, em posição frontal, que se move lentamente para frente.

A transposição da descrição do espaço físico do romance para o filme é feita aqui pelo emprego do plano geral nas funções descritiva e dramática. A descrição do local é pertinente, porque tem implicações na história. Conforme Mascelli (2010, p. 34), "[s]empre que a localização dos atores no cenário for significativa para a história, devem-se mostrar suas entradas, saídas e seus movimentos em planos gerais". Faz-se necessário situar a posição e a distância das personagens no espaço fílmico, particularmente na cena da fonte, para auxiliar o espectador a construir o sentido do texto. O primeiro plano geral deste trecho da sequência traz a visão da escadaria, de frente, o que dá uma ideia da dimensão do local. Na continuidade da sequência, há outra tomada de cena, em plano geral, em que Robbie e 
Cecilia estão, de costas, caminhando em direção à fonte. A noção de espacialidade é construída pelo jogo com a profundidade de campo e um enquadramento frontal, centralizando a fonte como plano de fundo, no final do vasto gramado verde, que se estende na frente da casa, dando um valor descritivo ao plano geral.

O próximo plano geral é feito em direção oposta, da fonte para a casa, e exibe os detalhes da figura do Tritão, no canto direito do quadro, e Robbie e Cecilia em meio à vastidão do cenário, com a imponência da casa ao fundo e do bosque ao lado da casa. Esta tomada adquire um valor dramático, pois é feita exatamente quando o conflito de classes aflora na conversa entre Robbie e Cecilia. Robbie sente-se no dever de restituir ao pai de Cecilia o dinheiro gasto com sua educação. Esta intenção anunciada por Robbie acaba por expor o abismo econômico entre os dois. Segundo Marcel Martin (2003, p. 38, grifos do autor), "[r] eduzindo o homem a uma silhueta minúscula, o plano geral o reintegra no mundo, faz com que as coisas o devorem, 'objetiva-o'; daí uma tonalidade psicológica bastante pessimista, uma ambiência moral um tanto negativa [...]”. Na imagem em tela, o cenário grandioso parece esmagar as figuras diminutas de Robbie e de Cecilia, tornando-os apenas 'objetos' de um contexto. Esta questão reporta-se à 'coisificação' do humano na sociedade capitalista, intensamente estratificada, onde o capital tem mais valor do que o ser. É, portanto, muito significativo que este cenário seja constituído pela casa de campo, símbolo da burguesia, representada em Atonement pela família Tallis, que frustra os planos de ascensão social de Robbie, o separa de Cecilia e provoca sua destruição. A questão do conflito de classes é, assim, transmutada para a adaptação fílmica através do uso dramático do plano geral e do diálogo.

$\mathrm{O}$ desenvolvimento da cena junto à fonte caracteriza-se pelo uso do campo e contracampo, que equivale a um diálogo, em combina- 
ção com o uso do close up, que traduz a introspecção da narrativa. De fato, há um curto diálogo entre Robbie e Cecília na disputa pelo vaso, ocasionada pela insistência de Robbie em ajudar Cecilia e pela resistência de Cecilia, já irritada com o distanciamento de Robbie nos últimos dias. Inclusive, a informação sobre o valor do vaso, veiculada através dos pensamentos de Cecilia no romance, é transmutada para o canal sonoro e transcontextualizada dentro do debate sobre o conflito de classes, por meio do desdém de Robbie, em resposta à observação de Cecilia acerca da preciosidade do vaso: "Este pode ser nosso item mais precioso". No entanto, a montagem possibilita um diálogo mais intenso entre Robbie e Cecilia, principalmente através da troca de olhares entre as duas personagens.

Deste modo, após o mergulho de Cecilia na fonte, o close-up em Robbie revela a apreensão dele pela vida dela. Quando Cecília emerge das águas, cena após cena, o diálogo vai se desenvolvendo, através dos close-ups nas personagens, com o enquadramento frontal, em campo e contracampo, descortinando os sentimentos velados e denunciando a paixão existente. Conforme Martin (2003, p. 39), “[s] em dúvida, é no primeiro plano do rosto humano que se manifesta melhor o poder de significação psicológico e dramático do filme, e é este tipo de plano que constitui a primeira, e no fundo a mais válida, tentativa de cinema interior". Portanto, o uso dos close-ups tanto acentua a dramaticidade exigida pela instância diegética, quanto serve de recurso cinematográfico para a transposição da narrativa introspectiva do romance.

Nesta sequência, destacamos também a fragmentação de imagens, construída pelo enquadramento e pelo uso do close up. Durante a caminhada de Cecilia e Robbie à fonte, numa tomada em plano médio, a imagem do corpo de Robbie surge, à esquerda da tela, fragmentada (da cintura para baixo) e dividindo o quadro com a imagem de Ce- 
cilia, tendo a fonte como pano de fundo. Em um dado momento da sequência, vemos Cecilia sentada na borda da fonte entre o ramalhete de flores e o vaso quebrado; e, no canto esquerdo do quadro, vemos o braço de Robbie. Noutro momento, ainda em plano médio, do lado direito do quadro, vemos parte do corpo de Robbie, na altura da cintura, e sua mão, segurando a asa do vaso, e no fundo do quadro, Cecilia está se vestindo. Esta fragmentação é evidenciada pelo foco em partes do corpo humano, elemento profundamente relevante neste contexto narrativo, visto que está associado à linguagem do desejo. De fato, o momento epifânico desta sequência acontece quando Cecilia emerge da fonte e Robbie mostra-se extasiado com a visão sensual causada pela transparência da roupa de Cecília no corpo molhado. Observamos, aqui, a relação entre o olhar e o desejo, que estimula a pulsão escópica do espectador e o faz cúmplice de Robbie e de Cecilia.

A sequência fecha com o som da pancada que Briony dá na abelha e a repetição do close up do rosto de Briony. Aqui, notamos a importância dos close ups para veicular a dramaticidade que o momento exige, visto que um rosto na tela tem um impacto fenomenal sobre o espectador. Os close ups do rosto de Briony, repetidos e congelados provocam fragmentações, rompendo com a continuidade fílmica e demarcando a presença de Briony, cujo efeito contém uma forte carga psicológica. O posicionamento destes close ups, no início e no final da sequência, simboliza a presença ameaçadora e dominadora daquela que "tudo vê e tudo sabe" e, sobretudo, daquela que determinará o trágico futuro de Robbie. Enfim, ouve-se a música cadenciada do som de uma máquina de escrever - som que personifica o aspecto autoral da personagem. 


\section{Considerações finais}

Culpada ou inocente, verdade ou mentira, ficção ou realidade, ética ou estética - a obra de McEwan se interpõe no espaço 'entre', levantando questionamentos que desestabilizam os aspectos constituídos para, enfim, propor uma saída pela configuração do espaço do outro: a ética da alteridade. Assim, o contexto ambíguo e cético de Atonement torna complexo e conflitante o entrelaçamento entre estas categorias dicotômicas. Porém, McEwan, através de Briony, argumenta a favor de uma ficção eticamente comprometida, apontando o enfrentamento da crise através da ética da alteridade, que sendo dialógica, contingencial e temporária, contempla a heterogeneidade e o contraditório no mundo contemporâneo. Para McEwan (apud ROBERTS, 2010, p. 70), "[n] ossa imaginação permite-nos entender o que é ser o outro". Consequentemente, o engajamento ideológico deste tipo de ficção transforma a leitura num ato ético, através das relações dialógicas entre leitor e personagens, promovidas pela introspecção e especuladas pela metaficção; e entre o leitor e o texto, mantendo o vínculo arte-vida.

\section{Notas}

1. Este trabalho é derivado da minha tese de doutorado intitulada "Jogo de Espelhos em Atonement: trajetórias e implicações da metaficcionalidade no romance e no filme", defendida em maio de 2013, sob a orientação da Prof $^{a}{ }^{2}{ }^{a}$ Genilda Alves de Azerêdo Rodrigues.

2. Todas as traduções dos textos em inglês (ver bibliografia) são de minha autoria.

3. Conforme a mitologia, "Tritão, filho de Netuno e de Anfitrite, era um semideus marinho; a parte superior do seu corpo até os rins figurava um homem nadando, a parte inferior era de um peixe de longa cauda. Era o 
arauto do deus do mar, a quem precedia sempre, anunciando a sua chegada ao som de uma concha recurva; algumas vezes é trazido à superfície das águas, outras vezes aparece em um carro puxado por cavalos azuis" (COMMELIN, P. Nova mitologia grega e romana. Tradução de Thomaz Lopes. Rio de Janeiro: Edições de ouro, s.d, p. 115).

4. McEWAN, Ian. Atonement. New York: Anchor Books, 2001. ao longo do texto, as referências serão identificadas apenas com o número da página, referente a esta edição. Como mencionado anteriormente, as traduções das passagens extraídas do romance são minhas.

5. O crítico inglês Cyril Vermon Connolly (1903-1974) foi realmente o editor da revista literária Horizon, entre 1940 a 1949.

6. Lembremos que, conforme Friedman (1967, p. 127-128), na onisciência seletiva múltipla "a história vem diretamente das mentes das personagens", com as marcas das impressões e percepções que acontecimentos e 'pessoas' deixam nessas personagens. Todo o material que compõe a história é "transmitido ao leitor apenas através da mente de alguém presente"; portanto, os pensamentos, percepções e sentimentos são filtrados pelas mentes das personagens, enquanto que o narrador onisciente neutro "resume-os e explica-os depois de terem ocorrido". Em Atonement, estas categorias são problematizadas pela ingerência da metaficção.

7. "A câmera é dita subjetiva quando ela assume o ponto de vista de uma das personagens, observando os acontecimentos de sua posição, e, digamos com os seus olhos" (XAVIER, 2008, p. 34).

8. No plano médio os "atores são filmados acima dos joelhos ou logo abaixo da cintura" (MASCELLI, 2010, p. 35).

9. Corte seco é "a passagem de um plano a outro por uma simples colagem, sem que o raccord seja marcado por um efeito de ritmo ou por uma trucagem" (AUMONT; MARIE, 2007, p. 66). Trucagem é "toda manipulação na produção de um filme que acaba mostrando na tela alguma coisa que não existiu na realidade" (AUMONT; MARIE, 2007, p. 293).

10. A plongée - expressão referente à angulação da câmara que significa 'filmagem de cima para baixo’ e acrescenta uma significação psicológica à cena (MARTIN, 2003, p. 41). 
11. Conforme Laura Mulvey (2008, p. 440-441), o conceito de escopofilia foi originalmente apresentado por Freud na obra Três ensaios sobre a teoria da sexualidade, "como um dos instintos componentes da sexualidade, que existem como pulsões, independentemente das zonas erógenas. Nesse ponto ele associou a escopofilia com o ato de tornar as outras pessoas como objetos, sujeitando-as a um olhar fixo, curioso e controlador"

12. Os narratólogos André Gaudreault e François Jost (2009, p. 167- 168, grifos dos autores) argumentam que o termo 'focalização', postulado por Gérard Genette, torna-se problemático quando aplicado ao cinema, "porque o filme sonoro pode mostrar o que o personagem vê e dizer o que ele está pensando". Portanto, estes teóricos cunham o termo 'ocularização' para caracterizar "a relação entre o que a câmara mostra e o que o personagem deve ver", distinguindo entre ponto de vista visual e ponto de vista cognitivo.

13. "Contracampo é uma figura de decupagem que supõe uma alternância com um primeiro plano então chamado de "campo". O ponto de vista adotado no contracampo é inverso daquele adotado no plano precedente, e a figura formada dos dois planos sucessivos é chamada de "campocontracampo"' (AUMONT; MARIE, 2007, pp. 61-2). O campo-contracampo indica uma interação entre os atores da cena.

14. Travelling refere-se ao deslocamento da câmera, "no qual permanecem constantes o ângulo entre o eixo ótico e a trajetória do deslocamento" (MARTIN, 2003, p. 47).

15. O espelhamento é o processo pelo qual a imagem é duplicada ou multiplicada no mesmo quadro, ao se refletir sobre uma superfície polida. O espelho é o instrumento per si para a construção do espelhamento.

\section{Referências}

AUMOUNT, Jacques; MARIE, Michel. Dicionário teórico e crítico de cinema. $3^{a}$ ed. Tradução de Eloisa Araújo Ribeiro. São Paulo: Papirus Editora, 2007.

CHILDS, Peter. (ed.). The fiction of Ian McEwan: a reader's guide to essential criticism. New York: Palgrave MacMillan, 2006.

COMMELIN, P.. Nova mitologia grega e romana. Tradução de Thomaz Lopes. Rio de Janeiro: Editora Tecnoprint Ltda, s.d. 
FREEDMAN, Norman. "Point of view in fiction: the development of a critical concept". In: STEVICK, Philip. (ed.). The theory of the novel. New York: The Free Press, 1967, p. 108-137.

GAUDREAULT, André; JOST, François. A narrativa cinematográfica. Tradução de Adalberto Müller, Ciro Inácio Marcondes e Rita Jover Faleiros. Brasília: Editora Universidade de Brasília, 2009.

GENETTE, Gerard. Discurso da narrativa. Tradução de Maria Alzira Seixo. Lisboa: Veja Universidade, s.d.

HUTCHEON, Linda. A poetics of postmodernism: history, theory, fiction. New York and London: Routledge, 2000.

. Narcissistic narrative: the metafictional paradox. London: Routledge, 1980.

MARTIN, Marcel. A linguagem cinematográfica. Tradução de Paulo Neves. São Paulo: Editora Brasiliense, 2003.

MASCELLI, Joseph V. Os cinco cs da cinematografia: técnicas de filmagem. Tradução de Janaína Marcoantônio. São Paulo, Summus Editorial, 2010.

McEWAN, Ian. Atonement. New York: Anchor Books, 2001.

MULVEY, Laura. Prazer visual e cinema narrativo. In: XAVIER, Ismail. (org.). A experiência do cinema. $4^{\mathrm{a}}$ ed.. São Paulo: Edições Graal Ltda., 2008, p. 440-441.

ROBERTS, Ryan. (ed.). Conversations with Ian Mc Ewan. Jackson: University Press of Mississippi, 2010.

XAVIER, Ismail. O discurso cinematográfico. 4a ed. São Paulo: Graal, 2008.

WAUGH, Patricia. Metafiction: the Theory and Practice of Self-conscious Fiction. London and New York: Routledge, 1984.

(Recebido em 30/07/2013. Aprovado em 19/10/2013) 